i dagens velferdsstater, krever at leseren er litt fortrolig med økonomisk-matematiske resonnementer. Dette kapitlet, av Kåre Petter Hagen \& Fred Schroyen, er imidlertid så innsiktsfullt og tankevekkende at den som kommer igjennom det, vil ha fått meget å tenke på.

\section{Ole Berg}

Institutt for helseledelse og helseøkonomi Universitetet i Oslo

\section{Helseleder? Les og lytt!}

Nordby $\mathrm{H}$.

Kommunikasjon og helseledelse

136 s. Oslo: Cappelen Damm, 2009.

Pris NOK 249

ISBN 978-82-02-283490

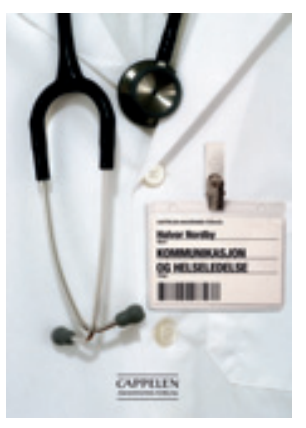

Etter et seminar med leger, skal filosofen Hans Skjervheim (1926-99) ha sagt: «Nå vet jeg forskjellen på oss. Dere fatter hundre avgjørelser om dagen, jeg bestemmer meg bare én gang $\mathrm{i}$ året.» Histo-

rien rant meg $i$ hu da jeg fikk denne boken, skrevet av en filosof, til anmeldelse. Er det mulig for en filosof å bidra med praktiske råd til helseledere, som knapt har et minutt til overs til kaffekoppen når de er på jobb?

Svaret viser seg å være ja. Bare formatet tyder på at forfatteren har forstått. Drøye 100 sider er lest på en kveldstime eller tre. Det er fire hoveddeler; Helseledelse, Kommunikasjonsutfordringer, Kommunikasjonsbetingelser og Praktisk kommunikasjon, hver med mange korte kapitler. Særlig i den siste delen hagler det med nyttige råd, men det vil være synd om leseren ikke tar seg bryet med å la bakgrunnsstoffet i de forutgående kapitlene synke inn.

Den første delen om helseledelse er snau, men konsentrert om hovedtemaer relevante for kommunikasjon. Vi hører om møtet mellom økonomifagene og helsefagene og verdikonflikten her. Begrepet forståelseshorisont, som stammer fra filosofen HansGeorg Gadamer (1900-2002), omtales kortfattet og brukes for å tydeliggjøre hvor vesentlig det er for en leder å skaffe seg informasjon om sine medarbeideres oppfatninger og verdier. Videre tar forfatteren for seg lederstil, mellommenneskelige relasjoner og kommunikasjonsteori. Det sier seg selv at på 20 sider blir disse temaene noe for summarisk gjennomgått.

Boken løfter seg derfor i de påfølgende avsnittene. Betydningen av begrep fra kommunikasjonsteorien, språk, oppmerk- somhet, assosiasjoner og holdninger og verdier utvikles her godt i helselandskapet, med profesjonsdominans, ressursknapphet, sårbarhet, et vidt spektrum av lidelse, paternalisme og medbestemmelse som kryssende dimensjoner. Det blir forståelig hvorfor og hvordan sykepleiere og leger som velger overordnede lederoppgaver, forandrer seg, ofte på en måte som ikke omtales rosende av dem som ble igjen på grunnplanet.

Det var med stor glede jeg så hvordan de teoretisk pregede kapitlene ledet logisk frem til ypperlige praktiske råd i siste del av boken. Her ble det mange utropstegn i margen, og hver gang tenkte jeg på ledere på alle nivåer jeg har møtt $i$ arbeidslivet. Kvintessensen burde være velkjent: Lytt mer, snakk mindre (og tydelig!) i enhver sammenheng! Men du verden, som det syndes mot disse enkle bud.

Litt malurt til slutt: Leseren må bære over med noen språklige bivirkninger av filosofisk behandling. Nokså ofte skriver forfatteren om hva han senere skal skrive mer om, boken kunne altså vært enda kortere. Og en setning som denne (s. 33) gir trolig kun mening for filosofer: «Videre vil jeg anta at det å være bevisst på utfordringer i kommunikasjon, er det samme som å være bevisst på kommunikasjonsutfordringer.» Dessuten var kjønnsperspektivet overraskende nok fullstendig fraværende. Bevisst?

\section{Pål Gulbrandsen}

Helse Sør-Øst kompetansesenter

for helsetjenesteforskning

Akershus universitetssykehus

Lørenskog

\section{Sosiologisk om funksjonshemning}

Kassah AK, Kassah BLL. Funksjonshemning

Sentrale ideer, modeller og debatter. 236 s, ill. Bergen: Fagbokforlaget, 2009. Pris NOK 367 ISBN 978-82-450-0825-8

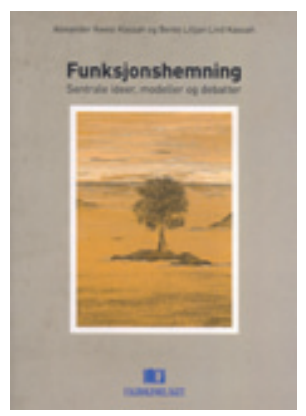

Målgruppen er «studenter, lærere og aktivister og alle som ønsker en bedre forståelse av funksjonshemning som begrep og som studie- og praksisfelt». Den er utformet som en lærebok og tilpasset studenter

og ansatte ved helse- og sosialfaglige utdanninger ved høyskoler og universiteter. Begge forfatterne er sosiologer.

Rekkefølgen på de 12 kapitlene er logisk, bibliografien er omfattende og det er med et kort stikkordsregister. Layouten er luftig, og boken inneholder ingen (!) illustrasjoner. Den er velskrevet, lett å lese og lett å finne frem $i$.

Forfatterne sier selv: «På denne reisen gjennom teorienes verden har vi gjort strandhugg i temaer som er sentrale innenfor fagfeltet som på engelsk heter Disability Studies, på norsk studier om funksjonshemning.» Tilnærmingen til stoffet er altså rent teoretisk. For å illustrere teoriene bruker forfatterne eksempler fra situasjoner som er både varierte og relevante. Første kapittel tar for seg ulike klassifikasjonsmodeller, hvordan disse er utviklet og hvor de står i forhold til hverandre. Deretter gjennomgås diskusjoner om kulturell forståelse, identitet, sosiale roller, avhengighet, normalitet og styrking (empowerment). Rehabilitering som begrep og praksis, ordningen med individuell plan og WHOs strategi med lokalsamfunnsbasert rehabilitering blir tatt opp. Det siste er den ene forfatterens spesialfelt og brukes i utviklingsland. Kapitlet om velferdsstatens historiske utvikling og velferdsordninger er utmerket. Så følger et litt langt kapittel om globalisering og hvordan den påvirker funksjonshemmedes livssituasjon. Sosial diskriminering, arbeidsdeltakelse, betydningen av kjønn og den verdiladede debatten om retten til å leve opp omtales. Barn og inkludering eller integrering i allmennskole kontra spesialskole er viet et eget kapittel. Sluttkapitlet om forskning og kunnskapsutvikling synes å være vel omfattende for formålet, men inneholder også en poengtert og oversiktlig tabell over ulike paradigmer innen forskning om funksjonshemning.

Denne anmelderen har ikke faglig tyngde til å se boken i sammenheng med annen sosiologisk litteratur. Sett fra klinikerens ståsted, er det sosiologiske perspektivet berikende og iblant klargjørende. Min favoritt ble avsnittene om individuell plan og arbeidet $i$ ansvarsgrupper - enkelt beskrevet og satt i et perspektiv til å bli atskillig klokere av enn Helsedirektoratets veiledere på området. Men: Jeg savner et kapittel om migranter bosatt i Norge - i det minste kunne noen eksempler vært tatt fra denne populasjonen.

Dette er kort sagt en lærebok jeg gjerne ser at mine fremtidige høyskoleutdannede samarbeidspartnere har hatt på pensumlisten. For folk som allerede arbeider med funksjonshemmede og/eller har undervisningsoppgaver innen feltet, er den ryddig, lettlest og leseverdig.

\section{Kjersti Ramstad}

Barneklinikken

Oslo universitetssykehus, Rikshospitalet 